\title{
POLA INVESTASI TENAGA KERJA WANITA INDONESIA DI DESA SIKANCO KECAMATAN NUSAWUNGU KABUPATEN CILACAP
}

\author{
Oleh : \\ Siti Ma'sumah \\ sitimasumah@iainpurwokerto.ac.id
}

\begin{abstract}
ABSTRAK
Islam mengajarkan bahwa suami wajib menafkahi keluarga. Namun tidak sedikit wanita yang baru bekerja setelah mereka menikah untuk membantu ekonomi keluarga. Latar belakang keluarga yang tidak mampu menyebabkan orang tidak memiliki pendidikan tinggi. Pendidikan yang rendah membuat orang bekerja pada sektor informal dengan gaji yang relatif rendah. Rendahnya gaji yang diterima tidak mampu mencukupi kebutuhan seharihari, terutama kebutuhan sandang dan papan. Kekurangan tersebut memicu para istri untuk bekerja diluar negeri dengan gaji yang tinggi walaupun mereka bekerja disektor informal. Penelitian ini bertujuan untuk menggambarkan pola investasi tenaga kerja wanita Indonesia di Desa Sikanco Kecamatan Nusawungu Kabupaten Cilacap.

Hasil penelitian ini menyimpulkan bahwa informan yang berinvestasi dalam tabungan cukup banyak namun seiring berjalannya waktu tabungan mereka habis digunakan untuk mencukupi kebutuhan sehari-hari. Mayoritas informan tidak berinvestasi dalam deposito, hanya satu orang yang pernah berinvestasi dalam deposito. Namun seiring berjalanya waktu setelah pulang ke Indonesia deposito itupun habis karena informan tidak memiliki penghasilan, sehingga menggunakan uang depositonya untuk mencukupi kebutuhan hidup. Tidak ada informan yang berinvestasi dalam bentuk saham. Hal ini karena ketidaktahuan informan maupun keluarganya tentang investasi dalam bentuk saham. Mayoritas informan berinvestasi dalam properti karena di desa investasi properti lebih banyak dipilih. Investasi dalam
\end{abstract}


barang koleksi seperti motor dan mobil cukup diminati oleh informan karena dapat digunakan sebagai alat transportasi. Mayoritas responden berinvestasi dalam emas, karena selain berinvestasi emas bisa dijadikan perhiasan. Tenaga kerja wanita yang menjadi responden dalam penelitian ini banyak yang menyimpan mata uang asing, namun habis seiring berjalannya waktu. Tidak ada responden yang berinvestasi dalam obligasi, karena ketidak tahuan informan dan keluarganya mengenai obligasi.

Kata kunci : Tenaga Kerja Wanita, Tabungan, Deposito, Saham, Properti, Barang-barang koleksi, Emas, Mata uang asing serta Obligasi.

\begin{abstract}
Islam teaches that husbands are obliged to provide for their families. But not a few women are just working after they get married to help the family's economy. Family background that is not capable of causing people not to have higher education. Low education makes people work in the informal sector with relatively low salaries. The low salary received is not enough to meet daily needs, especially the needs of clothing and shelter. This shortage triggered the wives to work abroad with high salaries even though they worked in the informal sector. This study aims to describe the investment pattern of Indonesian female workers in Sikanco Village, Nusawungu, Cilacap District.

The results of this study concluded that the informants who invest in savings are many but over time their savings are used up to meet their daily needs. The majority of female workers do not invest in deposits, only one person has ever invested in deposits. However, as time went on after returning to Indonesia, the deposit was used up because migrant workers did not have income, so they used the deposit money to sufficient needs. There are no migrant workers who invest in shares. This is because of the ignorance of the migrant workers and their families about investing in shares. The majority of informants invest in property because it is in the investment village because more investment villages are chosen. Investment in collectibles such as motorbikes and cars is quite attractive to informants because it can be used as a means of transportation. The majority of respondents invest in gold,
\end{abstract}


because in addition to investing in gold can be used as jewelry. Many female workers who were respondents in this study kept foreign currency, but it ran out over time. There are no respondents who invest in bonds, because of the unknown knowledge of migrant workers and their families regarding bonds.

Keywords: Female Labor, Savings, Deposits, Stocks, Property, Collectibles, Gold, Foreign Currencies And Bonds.

\section{PENDAHULUAN}

\section{A. Latar Belakang Masalah}

Islam mengajarkan bahwa suami wajib menafkahi keluarga. Kewajiban tersebut tercantum dalam QS. Ath Thalaq: 7, QS. Al Baqarah: 233, serta QS. Ath Thalaq: 8. Serta dalam salah satu hadits Riwayat Abu

Daud yang menyebutkan bahwa "Kewajiban seorang suami terhadap isterinya ialah suami harus memberi makan kepadanya jika ia makan dan memberi pakaian kepadanya jika ia berpakaian dan tidak boleh memukul mukanya dan tidak boleh memperolokkan dia dan juga tidak boleh meninggalkannya kecuali dalam tempat tidur (ketika isteri membangkang)."

Berdasarkan dalil dari Al-Quran dan hadis tersebut sebagian besar laki-laki berusaha semaksimal mungkin untuk memberi nafkah kepada keluarga. Namun pada kenyataanya, tidak sedikit wanita yang bekerja untuk membantu ekonomi keluarga. Sebagian wanita yang bekerja setelah menikah karena mereka telah bekerja sebelum mereka menikah. Namun tidak sedikit wanita yang baru bekerja setelah mereka menikah untuk membantu ekonomi keluarga. Hal itu banyak terjadi pada pasangan suami istri yang belum lama menikah.

Kebutuhan ekonomi untuk mengarungi hidup rumah tangga, memaksa pasangan muda untuk bekerja. Kebutuhan tersebut antara lain kebutuhan untuk memenuhi kehidupan sehari-hari baik sandang, pangan maupun papan. Kekurangan kebutuhan ekonomi tersebut biasanya terjadi pada pasangan yang berasal dari keluarga tidak mampu, karena 
orang tua mereka juga tidak mampu membantu untuk memenuhi kebutuhan hidup berumah tangga.

Latar belakang keluarga yang tidak mampu menunjukkan bahwa pasangan muda tersebut tidak memiliki pendidikan tinggi. Pendidikan yang rendah membuat pasangan muda bekerja pada sektor informal dengan gaji yang relatif rendah. Rendahnya gaji yang diterima oleh pasangan muda tidak mampu mencukupi kebutuhan sehari-hari, terutama kebutuhan sandang dan papan. Kekurangan tersebut memicu para istri untuk bekerja diluar negeri dengan gaji yang tinggi walaupun mereka bekerja disektor informal.

Di Desa Sikanco Kecamatan Nusawungu Kabupaten Cilacap terdapat banyak wanita yang bekerja keluar negeri. Mereka bekerja di Malaysia, Singapura, Hong Kong, Taiwan, Arab Saudi dan lain-lain. Sebagian besar mereka bekerja diluar negeri untuk membantu ekonomi keluarga. Oleh karena itu, fokus utama mereka adalah untuk memenuhi kebutuhan sandang, pangan dan papan. Biasanya mereka akan pulang setelah mereka memiliki rumah dan sawah. Sedikit sekali tenaga kerja wanita yang menginvestasikan uangnya dalam dunia usaha karena minimnya pengetahuan, pengalaman dan keterampilan. Sehingga mereka akan memilih untuk pergi bekerja diluar negeri lagi ketika usaha mereka tidak mampu memenuhi kebutuhan keluarga.

\section{B. Rumusan Masalah}

Rumusan masalah penelitian ini adalah bagaimana pola investasi tenaga kerja wanita Indonesia.

\section{Tujuan dan Kegunaan Penelitian}

\section{Tujuan Penelitian}

Penelitian ini bertujuan untuk menggambarkan pola investasi tenaga kerja wanita Indonesia.

\section{Kegunaan Penelitian}

a. Kegunaan Teoritis

Menambah wawasan dan khasanah pengetahuan mengenai pola investasi tenaga kerja wanita Indonesia. 
b. Kegunaan Praktis

Hasil penelitian ini dapat dijadikan dasar bagi pemerintah dalam mengarahkan pola investasi tenaga kerja wanita Indonesia yang produktif.

\section{Telaah Pustaka Penelitian Terkait}

Ada beberapa penelitian terdahulu yang relevan dengan penelitian ini, antara lain:

1. Hamidah dan Farida (2017) melakukan penelitian tentang Analisis Prioritas Investasi Keluarga Tenaga Kerja Indonesia (TKI) Di Kecamatan Babadan Kabupaten Ponorogo. Hasil penelitiannya menunjukkan bahwa Investasi dalam bentuk property merupakan prioritas yang dipilih TKI dan keluarganya di Kecamatan Babadan Kabupaten Ponorogo dikarenakan beberapa alasan yaitu : a) Kebutuhan TKI dan keluarga akan tempat tinggal yang layak, b) Lahan pertanian tidak akan turun nilainya di masa mendatang, c) Mata pencaharian turun temurun adalah pertanian, d) Tidak memiliki ketrampilan yang memadai dalam bidang yang lain, e)

Kurangnya keberanian mencoba usaha baru, f) Resiko dianggap rendah. Adapun pihak maupun alasan yang paling berpengaruh dalam

menentukan keputusan investasi keluarga TKI antara lain : a) Suami/istri dari TKI yang bekerja ke luar negeri, b) Ayah/ibu kandung dari TKI yang tinggal dengan orang tuanya, c) Melihat keberhasilan teman sesama TKI, d) Keberhasilan maupun kegagalan usaha yang dilakukan tetangga di sekitarnya yang juga menjadi TKI, e) Jumlah modal yang dapat dikumpulkan dari kerja ke luar negeri.

2. Karlina dkk (2017) melakukan penelitian tentang Pengaruh Bekerja Di Luar Negeri Terhadap Tingkat Ekonomi Dan Perceraian. Hasil penelitian tersebut menyimpulkan bahwa sebelum bekerja ke luar negeri kehidupan ekonomi keluarga tergolong rendah tetapi sesudah bekerja di luar negeri menjadi kehidupan ekonomi mereka mengalami peningkatan yang signifikan. Terkait dengan perceraian, 
tidak terdapat pengaruh yang signifikan karena hanya dialami oleh sebagian kecil keluarga yang bekerja di luar negeri

3. Sugiono dkk (2017) melakukan penelitian tentang Interpretasi Dampak Keuangan Keluarga Tenaga Kerja Wanita (Studi Fenomenologi TKW Pamekasan Yang Berimigrasi Ke Saudi Arabia Dan Malaysia). Penelitian tersebut menyimpulkan bahwa dampak keuangan keluarga TKW Pamekasan yang berimigrasi ke Saudi Arabia dan Malaysia memang ada walaupun tidak terlalu signifikan namun menurut pandangan mereka sangat berarti karena membawa banyak perubahan terhadap kehidupannya terutama yang berupa "aset rumah dan tanah", pendidikan anak-anaknya dan pemenuhan hidup keluarga yang ditinggalkannya. Para TKW Pamekasan ini sudah dapat merubah tempat tinggalnya yang semula terbuat dari "gedek" menjadi rumah bangunan permanen. Dalam hal pendidikan sebagian TKW sudah berhasil menyekolahkan anakanaknya sampai tingkat pendidikan menengah bahkan ada yang sampai lulus perguruan tinggi. Selain itu dampak keuangan lainnya adalah tersedianya modal usaha bagi mereka untuk membuka usaha baru baik berupa took "pracangan" kecil-kecilan maupun usaha yang lain sebagai jaminan untuk bisa bertahan hidup setelah kepulangannya ke Indonesia.

Sedangkan dampak lainnya berupa "harta tidak berwujud" yaitu berupa kepuasan hati karena dapat menunaikan rukun Islam yang ke Lima (naik haji) bagi TKW yang berimigrasi ke Saudi Arabia.

4. Penelitian lain dilakukan oleh Raharto (2017) tentang Pengambilan Keputusan Tenaga Kerja Indonesia (TKI) Perempuan Untuk Bekerja Di Luar Negeri: Kasus Kabupaten Cilacap. Hasil penelitiannya menyimpulkan bahwa perempuan tidak memiliki pilihan selain bekerja di luar negeri, terutama karena pertimbangan faktor ekonomi. Inisiatif untuk bekerja umumnya datang dari perempuan sendiri, sedangkan anggota keluarga terutama ayah dan suami hanya memberikan persetujuan. Dengan demikian, perempuan sudah lebih memiliki kebebasan dan kepercayaan diri untuk memutuskan bekerja di luar negeri. 


\section{E. Kerangka Teori}

\section{Investasi}

Pengertian Investasi (Sunariyah 2003) "Investasi adalah penanaman modal untuk satu atau lebih aktiva yang dimiliki dan biasanya berjangka waktu lama dengan harapan untuk mendapatkan keuntungan di masa yang akan datang. Investasi dibedakan dalam bentuk aktiva riel (real assets) dan dalam bentuk surat berharga (financial assets)".

Investasi dalam ilmu Ekonomi Makro adalah pengeluaran atau perbelanjaan penanaman modal atau perusahaan untuk membeli barangbarang modal dan perlengkapan-perlengkapan untuk menambah kemampuan memproduksi barang-barang dan jasa-jasa yang tersedia dalam perekonomian (Sukirno, 2004).

\section{Jenis-jenis Invetasi}

Adapun bentuk-bentuk Investasi dalam ilmu ekonomi Makro yaitu berupa Investasi tanah, Investasi pendidikan, Investasi saham, Investasi barang modal dan bangunan, serta Investasi persediaan (Sukirno, 2004).

Investasi dapat berarti beberapa hal : pembelian saham oleh investor, investasi diri sendiri misalnya seorang pelajar dalam bentuk pembayaran biaya kuliah, investasi perusahaan dalam bentuk pabrik baru atau alat transportasi (Gorman, 2009).

Menurut Senduk (2004) bahwa produk-produk investasi yang tersedia di pasaran antara lain:

1. Tabungan di bank

2. Deposito di bank

3. Saham

4. Properti : Investasi dalam properti berarti investasi dalam bentuk tanah atau rumah. Keuntungan yang bisa didapat dari properti ada dua yaitu : Menyewakan properti tersebut ke pihak lain sehingga mendapatkan uang sewa. Serta menjual properti tersebut dengan harga yang lebih tinggi. 
5. Barang-barang koleksi (mobil, motor, lukisan, barang 99ntic lainnya)

6. Emas dan permata

7. Mata uang asing

8. Obligasi

\section{Tenaga Kerja Indonesia}

Pengertian tenaga kerja dalam Undang-Undang Nomor 13 Tahun 2003 tersebut menyempurnakan pengertian tenaga kerja dalam UndangUndang Nomor 14 tahun 1969 Tentang Ketentuan Ketentuan Pokok

Ketenagakerjaan yang memberikan pengertian "Tenaga Kerja adalah Setiap orang yang mampu melakukan pekerjaan baik di dalam maupun di luar hubungan kerja guna menghasilkan barang atau jasa untuk memenuhi kebutuhan masyarakat.

Tenaga Kerja Indonesia (disingkat TKI) adalah sebutan bagi warga negara Indonesia yang bekerja di luar negeri (Malaysia, Timur Tengah, Taiwan, Australia dan Amerika Serikat) dalam hubungan kerja untuk jangka waktu tertentu dengan menerima upah. Namun demikian, istilah TKI seringkali dikonotasikan dengan pekerja kasar. TKI perempuan seringkali disebut Tenaga Kerja Wanita (TKW). Keluarga TKI terdiri dari suami atau istri, ayah dan ibu kandung, ayah dan ibu mertua, adik, kakak, paman, bibi, saudara kandung anak - anak TKI sendiri, serta orang - orang terdekat lainnya.

Menurut Todaro (2006), kaum wanita di negara-negara berkembang pada umumnya terlalu banyak menangung beban kemiskinan, keterbatasan taraf pendidikan, kelangkaan lapangan pekerjaan yang memadai, serta mobilitas social yang minim. Sedangkan Menurut Sumarsono (2003), faktor tradisi, kebudayaan dan fisik menyebabkan terdapat perbedaan TPAK antara perempuan dan laki-laki. Laki-laki ditakdirkan lebih berat dari pada perempuan. Laki-laki ditempatkan pada posisi kepala rumah tangga dengan tanggung jawab menyertainya. Perempuan dipandang tidak pantas 
untuk bekerja, karena kebudayaan mengharuskan perempuan tidak bekerja melainkan mengurus rumah tangga.

\section{F. Metode Penelitian}

\section{Lokasi dan rancangan penelitian}

Lokasi penelitian ini berada dalam wilayah Desa Sikanco, Kabupaten Cilacap. Penelitian yang berlangsung dari bulan Maret hingga Agustus 2018 ini menggunakan metode kualitatif dan jenis penelitian yang digunakan adalah studi kasus.

2. Informan peneltian

Berdasarkan informasi dari perangkat Desa Sikanco diketahui bahwa jumlah wanita yang pernah atau sedang bekerja diluar negeri sekitar 34 orang. Untuk melihat penggunaan uang hasil kerja diluar negeri peneliti membuat strata sampel dengan ketentuan informan yang telah kembali ke Indonesia lebih dari 5 tahun, informan yang telah kembali ke Indonesia sampai dengan 5 tahun dan informan yang masih bekerja di luar negeri. Dari masing-masing strata diambil 3 orang responden. Tujuannya adalah untuk mengetahui efektifitas penggunaan uang hasil kerja walau sudah lama pulang dari luar negeri dan bisa bertahan tidak pergi lagi, serta peran keluarga dalam mengelola uang hasil kerja bagi TKW yang masih bekerja diluar negeri.

\section{Metode dan Instrumen Pengumpulan Data}

Metode pengumpulan data merupakan suatu cara apa dan bagaimana data yang diperlukan dapat dikumpulkan sehingga hasil akhir penelitian mampu menyajikan informasi yang valid dan reliable. Adapun metode dan alat pengumpulan data dalam penelitian ini adalah sebagai berikut:

a. Metode pengumpulan data penelitian

Metode pengumpulan data yang digunakan dalam penelitian ini adalah sebagai berikut :

1. Wawancara

Wawancara yaitu mengumpulkan informasi untuk mendapatkan pemahaman tentang fenomena yang akan 
diteliti. Wawancara adalah percakapan dengan maksud tertentu, percakapan itu dilakukan oleh dua belah pihak yaitu pewawancara (interviewer) yang mengajukan pertanyaan dan yang diwawancarai (interviewee) yaitu memberikan jawaban atas pertanyaan tersebut. Maksud wawancara seperti yang ditegaskan oleh Lincolin dan Guba (Moleong, 2012) antara lain : mengkonstruksi mengenai orang, kejadian, kegiatan, organisasi, perasaan, motivasi, tuntutan, kepedulian, dan lainlain.

Metode ini terdiri dari kutipan langsung mengenai pengalaman, opini dan perasaan (Alsa, 2010). Teknik ini dilakukan dengan menggunakan seperangkat pertanyaan baku. Pada penelitian ini metode wawancara yang digunakan adalah wawancara terstruktur yaitu wawancara yang pewawancaranya menetapkan sendiri masalah dan pertanyaan-pertanyaan yang akan diajukan (Moleong, 2012). Dalam penelitian ini, metode wawancara digunakan untuk mengungkap bagaimana pola investasi tenaga kerja wanita Indonesia.

2. Observasi

Observasi adalah kegiatan memperhatikan secara akurat, mencatat fenomena yang muncul dan mempertimbangkan hubungan aspek dalam fenomena tersebut dengan aktifitasaktifitas yang berlangsung serta makna kejadian, yang dilihat dari perspektif mereka yang terlihat.

Dalam penelitian ini metode observasi digunakan peneliti untuk mengamati dan kemudian mencatat perilaku subjek penelitian sesuai dengan apa yang sebenarnya terjadi (Moleong, 2012). Observasi dalam penelitian ini dilakukan secara partisipan karena dalam situasi dimungkinkan sekali orang-orang yang diajak bicara dan yang sedang diamati tidak menyadari bahwa sebenarnya mereka sedang diwawancarai secara sistematis untuk penggalian data. Observasi dalam penelitian ini digunakan untuk mengetahui pola investasi tenaga kerja wanita Indonesia.

3. Alat pengumpulan data 
Alat pengumpulan data yang digunakan dalam penelitian ini adalah sebagai berikut : a. Pedoman Wawancara

b. Pedoman Observasi

c. Buku catatan

d. Alat perekam / tape recoder

\section{Metode Analisis Data}

Analisis merupakan proses pencarian dan perencanaan secara sistematik semua data dan bahan lain yang telah terkumpul agar peneliti mengerti benar makna yang telah ditemukannya, dapat menyajikan kepada orang lain secara jelas.

Analisis data dalam penelitian kualitatif dilakukan pada saat pengumpulan data berlangsung dan setelah selesai pengumpulan data dalam periode tertentu. Menurut Miles dan Huberman (Sugiono, 2010), mengemukakan bahwa aktifitas dalam analisis data kualitatif dilakukan secara interaktif dan berlangsung secara terus menerus sampai tuntas, sehingga datanya sudah jenuh. Aktifitas dalam analisis data, yaitu reduction, data diplay, conclusion drawing / veryfying. Selanjutnya model interakfif dalam analisis data ditunjukan pada gambar sebagai berikut :

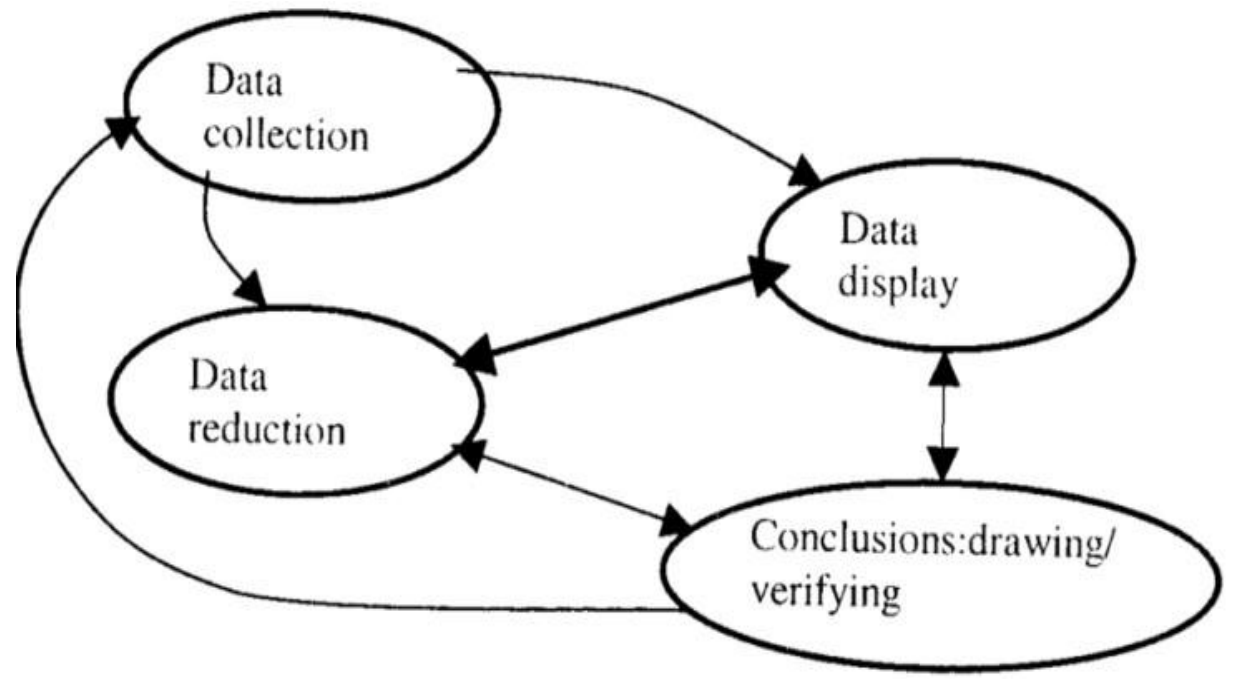

Gambar 2. Proses analisis data Sumber : Sugiyono, 2010 
Analisis data dalam penelitian ini menggunakan analisis data model interaktif (interaktif model of analysis). Dilakukan melalui tahapan sebagai berikut :

1. Pengumpulan data (Data colletion)

Pengumpulan data merupakan suatu proses atau kegiatan mengumpulkan data melalui kegiatan wawancara, observasi maupun dokumentasi untuk mendapatkan data yang lengkap.

2. Reduksi data (Reduction data)

Reduksi data (data reduction), yaitu proses pemilihan, pemusatan perhatian pada penyederhanaan, abstraksi dan transformasi data kasar yang diperoleh dilapangan.

3. Penyajian Data (Data display)

Deskripsi kumpulan informasi tersusun yang memungkinkan melakukan penarikan kesimpulan dan pengambilan tindakan

4. Penarikan Kesimpulan (Conclusion drawing / verification) Proses mencari makna dari setiap gejala yang diperoleh dilapangan, mencatat keteraturan atau pola penjelasan dan konfigurasi. Setiap kesimpulan yang telah ditentukan akan terus menerus diverifikasi sehingga benar-benar diperoleh konklusi yang valid.

\section{PEMBAHASAN}

\section{A. Hasil Penelitian}

a. Karakteristik informan penelitian

Karakteristik informan penelitian dapat dilihat dalam tabel berikut:

Tabel 4.1 Karakteristik informan penelitian

\begin{tabular}{|c|c|c|c|c|}
\hline Subjek & $\begin{array}{c}\text { Tempat } \\
\text { Kerja TKW }\end{array}$ & Alasan bekerja & Lama kerja & gaji \\
\hline $\mathrm{Ts}$ & Malaysia & Cari rizki & 10 tahun & $\mathrm{Rm} 1.200$ \\
\hline $\mathrm{Tu}$ & Hongkong & Tuntutan hidup & 4 tahun & $\$ 4.410$ \\
\hline $\mathrm{Ma}$ & Hongkong & Cari uang & 3 tahun & 6 juta \\
\hline $\mathrm{Si}$ & Hongkong & Cari uang & 2 tahun & $3-4$ juta \\
\hline $\mathrm{Ya}$ & Hongkong & Cari uang & 2 tahun & $3-4$ juta \\
\hline
\end{tabular}


Siti Ma'sumah : Pola Investasi Tenaga Kerja Wanita Indonesia di Desa Sikanco.....

\begin{tabular}{|c|c|c|c|c|}
\hline Subjek & $\begin{array}{c}\text { Tempat } \\
\text { Kerja TKW }\end{array}$ & Alasan bekerja & Lama kerja & gaji \\
\hline $\mathrm{Mu}$ & Singapura & Cari uang & 3 tahun & $3-4$ juta \\
\hline $\mathrm{Ta}$ & Hongkong & Cari duit & 2 tahun & $3-4$ juta \\
\hline $\mathrm{He}$ & Taiwan & Cari duit & 3 tahun & $4-5$ juta \\
\hline $\mathrm{Ha}$ & Taiwan & Ekonomi & 3 tahun & $4-5$ juta \\
\hline
\end{tabular}

b. Hasil observasi penelitian

1) Informan $T s$

Saat observasi Ts masih di Malaysia. Peneliti melakukan observasi kekeluarganya dan mendapat informasi kontak dari keluarga sehingga peneliti bisa kontak dengan informan. Bangunan rumah informan sudah tembok. Keluarga informan terlihat hidup tidak kekurangan karena mendapat uang dari informan. Anak informan bisa sekolah sampai SMA. Informan juga sering meberi uang kepada orang tua.

2) Informan $\mathrm{Tu}$

Saat observasi Tu masih di Hongkong. Peneliti melakukan observasi dengan keluarganya dan mendapat kontak dari keluarga sehingga bisa berkomunikasi dengan informan. Informan sedang membangun rumah didekat rumah orangtuanya namun belum selesai. Informan memiliki satu orang anak kelas 1 SD. Suami informan bekerja serabutan. Informan selalu memberi uang kepada orangtuanya karena anaknya diasuh oleh orangtuanya.

3) Informan $\mathrm{Ma}$

Ma baru pulang dari Hongkong. Ma sedang membangun rumah didekat rumah orangtuanya, namun rumah tersebut belum jadi dan belum dihuni. Ma juga sudang memiliki sawah. Saat ini Ma masih dengan orang tua karena masih single dan akan melangsungkan pernikahan sebentar lagi. Ma belum memiliki tanggungan karena orang tuanya juga memiliki kehidupan yang cukup baik karena ibunya juga pernah bekerja di Singapura dan Taiwan. 
4) Informan $\mathrm{Si}$

Si sudah cukup lama berada di Indonesia karena bekerja di Singapura pada tahun 2001-2003 dan bekerja di Hongkong pada tahun 2003-2005. Si sudah bisa menyelesaikan kuliah S1 dari hasil kerja di luar negeri. Saat ini Si sudah memiliki rumah yang cukup bagus bagi masyarakat didesanya. Si juga sudah memiliki pekerjaan yang cukup untuk memenuhi kebutuhan keluarga.

5) Informan $Y a$

Ya merupakan ibu (keluarga) dari TKW yang bekerja di Hongkong. Ya memiliki rumah yang cukup baik bagi masyarakat didesanya. Ya sering menerima kiriman uang dari anaknya karena anaknya masih single. Uang tersebut Ya simpan dan kadang digunakan untuk menyewa sawah, kadang juga gadai sawah.

6) Informan $\mathrm{Mu}$

$\mathrm{Mu}$ baru pulang dari Singapura. Mu memiliki rumah serta memiliki toko kelontong kecil. Karena selama di Singapura uangnya buat membuat toko oleh keluarganya. Mu baru menikah setelah pulang dari Singapura kemarin, sehingga tidak memiliki tanggungan. Kadang Mu memberi uang untuk orangtuanya. Selama di Singapura Mu mengirimkan uangnya kepada orantuanya dan digunakan untuk membuat toko.

7) Informan $\mathrm{Ta}$

Ta pernah bekerja di Singapura, Taiwan dan Hongkong. Dari hasil bekerja di luar negeri dia bisa membeli tanah dan membangun rumah. Ruamh Ta cukup baik bagi masyarakat didesanya. Selama bekerja menjadi TKW Ta masih single sehingga tidak memiliki tanggunan. Namun uangnya dia kirimkan keorang tuanya.

8) Informan He

He baru pulang dari Taiwan. Selama di Taiwan dia mengirimkan uangnya kepada orang tua karena dia masih single. Namun He juga membantu orang tuanya untuk 
memenuhi hidup sehari-hari dan juga membantu menyekolahkan adiknya karena orangtuanya tidak memiliki pekerjaan tetap dengan penghasilan tidak pasti.

9) Informan $\mathrm{Ha}$

Ha pernah bekerja di Taiwan. Ha sudah punya rumah yang cukup baik bagi masyarakat di desanya. Ha juga punya kendaraan bermotor. Ha sudah berkeluarga sehingga dia juga menghidupi keluarganya. Suami Ha bekerja serabutan. Selain dia menghidupi anakknya dia juga membantu orangtuanya karena anakknya diasuh orang tuanya saat dia bekerja diluar negeri.

\section{Tabel 4.2 Ringkasan Wawancara}

\begin{tabular}{|c|c|c|c|c|c|c|c|c|c|}
\hline \multirow[t]{2}{*}{ Sub indikator } & \multicolumn{9}{|c|}{ Informan } \\
\hline & 1 & 2 & 3 & 4 & 5 & 6 & 7 & 8 & 9 \\
\hline $\begin{array}{l}\text { Alasan menjadi } \\
\text { TKW }\end{array}$ & Cari rizki & $\begin{array}{l}\text { Tuntutan } \\
\text { hidup }\end{array}$ & Cari uang & $\begin{array}{l}\text { Cari } \\
\text { uang }\end{array}$ & Cari uang & Cari uang & Cari uang & Cari uang & Ekonomi \\
\hline $\begin{array}{l}\text { Penggunaan hasil } \\
\text { kerja }\end{array}$ & $\begin{array}{l}\text { Mencukupi } \\
\text { kebutuhan }\end{array}$ & $\begin{array}{l}\text { Membantu } \\
\text { orangtua dan } \\
\text { ditabung }\end{array}$ & $\begin{array}{l}\text { Ditabung dan } \\
\text { membantu } \\
\text { orang tua }\end{array}$ & Ditabung & $\begin{array}{l}\text { Ditabung } \\
\text { untuk masa } \\
\text { depan }\end{array}$ & $\begin{array}{l}\text { Membantu } \\
\text { keluarga, } \\
\text { beli tanah, } \\
\text { rumah dan } \\
\text { toko }\end{array}$ & $\begin{array}{l}\text { Membantu } \\
\text { keluarga, } \\
\text { tabungan } \\
\text { dan } \\
\text { membeli } \\
\text { tanah }\end{array}$ & $\begin{array}{l}\text { Kebutuhan } \\
\text { keluarga } \\
\text { dan } \\
\text { ditabung }\end{array}$ & $\begin{array}{l}\text { Modal dan } \\
\text { membantu } \\
\text { orang tua }\end{array}$ \\
\hline $\begin{array}{l}\text { Investasi dalam } \\
\text { tabungan }\end{array}$ & Tidak & Tidak & $\mathrm{Ya}$ & $\mathrm{Ya}$ & $\mathrm{Ya}$ & $\mathrm{Ya}$ & Tidak & $\mathrm{Ya}$ & $\mathrm{Ya}$ \\
\hline $\begin{array}{l}\text { Investasi dalam } \\
\text { deposito }\end{array}$ & Tidak & Tidak & Tidak & Tidak & Tidak & Tidak & Tidak & Tidak & $\mathrm{Ya}$ \\
\hline $\begin{array}{l}\text { Investasi dalam } \\
\text { saham }\end{array}$ & Tidak & Tidak & Tidak & Tidak & Tidak & Tidak & Tidak & Tidak & Tidak \\
\hline $\begin{array}{l}\text { Investasi dalam } \\
\text { tanah atau rumah }\end{array}$ & $\mathrm{Ya}$ & $\mathrm{Ya}$ & $\mathrm{Ya}$ & Tidak & Tidak & $\mathrm{Ya}$ & $\mathrm{Ya}$ & $\mathrm{Ya}$ & $\mathrm{Ya}$ \\
\hline $\begin{array}{l}\text { Investasi dalam } \\
\text { kendaraan }\end{array}$ & Tidak & Tidak & Tidak & Tidak & Tidak & $\overline{Y a}$ & $\overline{Y a}$ & $\overline{Y a}$ & $\overline{Y a}$ \\
\hline $\begin{array}{l}\text { Investasi dalam } \\
\text { emas dan permata }\end{array}$ & $\mathrm{Ya}$ & Tidak & Tidak & $\mathrm{Ya}$ & $\mathrm{Ya}$ & $\mathrm{Ya}$ & $\mathrm{Ya}$ & Tidak & $\mathrm{Ya}$ \\
\hline $\begin{array}{l}\text { Investasi dalam } \\
\text { mata uang asing }\end{array}$ & $\overline{Y a}$ & $\mathrm{Ya}$ & $\mathrm{Ya}$ & Tidak & Tidak & Tidak & Tidak & $\overline{Y a}$ & $\overline{Y a}$ \\
\hline $\begin{array}{l}\text { Investasi dalam } \\
\text { obligasi }\end{array}$ & Tidak & Tidak & Tidak & Tidak & Tidak & Tidak & Tidak & Tidak & Tidak \\
\hline
\end{tabular}

\section{B. Pembahasan}

Tenaga kerja wanita Indonesia yang bekerja di luar negeri sebagian besar berpendidikan rendah dan sedang karena berasal dari masyarakat dengan ekonomi lemah. Maka mayoritas alasan mereka bekerja di luar negeri untuk mencari uang. Uang yang mereka peroleh 
digunakan untuk membiayai kebutuhan hidupnya dan keluarga. Setelah itu barulah mereka membuat rumah dan membeli sawah untuk investasi. Karena TKW dalam penelitian ini berasal dari desa maka mereka tidak mengetahui jenis-jenis investasi seperti saham, obligasi, deposito dan lainlain.

Investasi menurut Hartono (2016) adalah penundaan konsumsi sekarang untuk dimasukkan keaktiva produktif selama periode waktu yang tertentu. Menurut pengertian tersebut sebenarnya para TKW belum menerapkannya secara maksimal karena mayoritas mereka baru membangun rumah untuk dihuni bukan untuk disewakan sebagai aktiva produktif.

Alasan mayoritas responden tidak berinvestasi dalam aktiva produktif seperti saham, obligasi, deposito dan lain-lain karena ketidak tahuan mereka tentang jenis investasi tersebut. Namun hal tersebut dapat diatasi dengan mempercayakan modalnya kepada para manajer investasi. Dengan berinvesatasi pada sebuah perusahaan dengan kata lain memiliki saham sebuah perusahaan merupakan pilihan yang cukup bagus untuk para TKW yang rata-rata berpendidikan rendah dan sedang. Karena menurut Hanafi (2017) para manajer keuangan memiliki tugas untuk mengambil keputusan investasi, pendanaan dan likuiditas dengan tujuan memaksimumkan kemakmuran pemegang saham.

Menurut Senduk (2004) bahwa produk-produk investasi yang tersedia di pasaran antara lain:

1. Tabungan di bank

Informan yang berinvestasi dalam tabungan cukup banyak yaitu 6 orang sedangkan yang tidak berinvestasi dalam tabungan hanya 3 orang itu pun karena mereka masih bekerja diluar negeri dan uangnya dikirimkan ke Indonesia dan mempercayakan sepenuhnya kepada keluarga dalam pengelolaannya. Tidak semua TKW tidak memiliki tabungan selama diluar negeri, sebenarnya mereka 
disarankan memiliki tabungan namun rekening tabungan itu hanya buat menampung gaji sebelum dikirimkan ke Indonesia bagi TKW yang mendapat gaji secara cek. Namun bagi TKW yang menerima gaji secara kontan mayoritas mereka tidak memiliki tabungan atas nama sendiri, namun tabungannya di rekening orangtua karena dikirimkan ke orangtua mereka. Dengan kata lain walaupun mereka tidak memiliki tabungan atas nama mereka namun mereka tetap memiliki tabungan.

Tabungan TKW mayoritas tidak bertahan lama. Setelah pulang ke Indonesia tabungan mereka habis karena mayoritas tidak memiliki penghasilan sehingga mereka menggunakan uang tabungan mereka untuk memenuhi kebutuhan sehari-hari. Selain habis digunakan untuk investasi dalam bentuk lain seperti tanah, rumah maupun kendaraan.

Menurut Undang-undang No 10 Tahun 1998 Tentang Perbankan, Tabungan adalah simpanan yang penarikannya hanya dapat dilakukan menurut syarat tertentu yang disepakati, tetapi tidak dapat ditarik dengan cek, bilyet giro, dan latau alat lainnya yang dipersamakan dengan itu.

Penelitian ini senada dengan penelitain Sugiono dkk (2017) melakukan penelitian tentang Interpretasi Dampak Keuangan Keluarga Tenaga Kerja Wanita (Studi Fenomenologi TKW Pamekasan Yang Berimigrasi Ke Saudi Arabia Dan Malaysia). Penelitian tersebut menyimpulkan bahwa dampak keuangan keluarga TKW Pamekasan yang berimigrasi ke Saudi Arabia dan Malaysia memang ada walaupun tidak terlalu signifikan namun menurut pandangan mereka sangat berarti karena membawa banyak perubahan terhadap kehidupannya.

2. Deposito di bank 
Mayoritas TKW tidak berinvestasi dalam deposito, hanya satu orang yang pernah berinvestasi dalam deposito. Namun seiring berjalanya waktu setelah pulang ke Indonesia deposito itupun habis karena TKW tidak memiliki penghasilan, sehingga menggunakan uang depositonya untuk memenuhi kebutuhan hidup. TKW jarang yang berinvestasi dalam bentuk deposito karena mereka telah menyimpan uang mereka dalam bentuk tabungan.

Minimnya TKW yang berinvestasi dalam bentuk deposito juga karena kurangnya pengetahuan mereka atau keluarga yang memegang uang mereka tentang investasi dalam deposito. Hal ini karena di Desa masih sedikit sekali informasi yang didapat oleh masyarakat mengenai deposito. Padahal bunga deposito lebih tinggi dari pada bunga tabungan. Seharusnya investasi dalam deposito lebih menguntungkan dari pada investasi dalam tabungan seperti halnya yang dilakukan oleh masyarakat desa sikanco.

Deposito atau yang sering juga disebut sebagai deposito berjangka, merupakan produk bank sejenis jasa tabungan yang biasa ditawarkan kepada masyarakat. Dana dalam deposito dijamin oleh pemerintah melalui Lembaga Penjamin Simpanan(LPS) dengan persyaratan tertentu. Deposito merupakan produk penyimpanan uang di bank dengan sistem penyetoran yang penarikannya hanya bisa dilakukan setelah melewati waktu tertentu. Bunga deposito biasanya lebih tinggi daripada bunga tabungan biasa. Bunga dapat diambil setelah tanggal jatuh tempo atau dimasukkan lagi ke pokok deposito untuk didepositokan lagi pada periode berikutnya.

Hamidah dan Farida (2017) melakukan penelitian tentang Analisis Prioritas Investasi Keluarga Tenaga Kerja Indonesia (TKI) Di Kecamatan Babadan Kabupaten Ponorogo. Hasil penelitiannya menunjukkan bahwa pihak maupun alasan yang paling berpengaruh dalam menentukan keputusan investasi keluarga TKI antara lain : a) 
Suami/istri dari TKI yang bekerja ke luar negeri, b) Ayah/ibu kandung dari TKI yang tinggal dengan orang tuanya, c) Melihat keberhasilan teman sesama TKI, d) Keberhasilan maupun kegagalan usaha yang dilakukan tetangga di sekitarnya yang juga menjadi TKI, e) Jumlah modal yang dapat dikumpulkan dari kerja ke luar negeri. 3. Saham

Hasil penelitian ini menunjukkan bahwa tidak ada TKW yang berinvestasi dalam bentuk saham. Hal ini karena ketidaktahuan TKW maupun keluarganya tentang investasi dalam bentuk saham. Ketidaktahuan TKW maupun keluarga TKW karena minimnya pengetahuan serta pendidikan mereka. Sebagian besar TKW dan keluarganya hanya berpendidikan sedang bahkan rendah. Tidak ada TKW yang berpendidikan tinggi sehingga dapat pengetahuan tentang investasi saham. Selain rendahnya pendidikan juga karena tidak adanya sosialisasi kepada masyarakat desa baik dari pemerintah maupun lembaga terkait mengenai investasi dalam saham.

Saham adalah sertifikat yang menunjukkan bukti kepemilikan suatu perusahaan dan pemegang saham memiliki hak klaim atas penghasilan dan aktiva perusahaan. Saham adalah surat bukti kepemilikan atas sebuah perusahaan yang melakukan penawaran umum (go public) dalam nominal atau presentase tertentu. Sementara itu, saham adalah jumlahnya bisa diputar dengan berbagai cara berdagang, dan harganya bisa berubah sewaktu-waktu tergantung keuntungan dan kerugian atau kinerja perusahaan tersebut (Indah, 2010).

Menurut Undang-Undang Perseroaan yang berlaku di indonesia, saham, adalah surat berharga yang dikeluarkan oleh sebuah perusahaan yang berbentuk Perseroaan Terbatas (PT) atau yang biasa disebut Emiten. Saham menyatakan bahwa pemilik saham tersebut adalah juga pemilik sebagian dari perusahaan tersebut. 
Dengan demikian apabila seseorang investor membeli saham, maka ia pun menjadi pemilik dan disebut pemegang saham perusahaan.

4. Properti

Mayoritas responden berinvestasi dalam properti. Hanya dua orang responden yang tidak berinvestasi di properti karena alasan masih single dan juga karena uangnya akan digunakan untuk sekolah lagi. Responden yang memilih berinvestasi dalam properti karena di desa investasi propertilah yang lebih banyak dilakukan. Properti yang diutamakan adalah rumah, jika belum punya tanahnya maka mereka akan membeli tanah baru dibangun rumah diatasnya. Properti lain yang diincar setelah memiliki tanah dan rumah adalah sawah. Sawah merupakan properti yang paling produktif di desa karena dengan memiliki sawah, para TKW bisa memiliki penghasilan setelah nanti pulang ke Indonesia.

Investasi dalam properti berarti investasi dalam bentuk tanah atau rumah. Keuntungan yang bisa didapat dari properti ada dua yaitu : Menyewakan properti tersebut ke pihak lain sehingga mendapatkan uang sewa. Serta menjual properti tersebut dengan harga yang lebih tinggi.

Penelitian ini sejalan dengan penelitain Sugiono dkk (2017) melakukan penelitian tentang Interpretasi Dampak Keuangan Keluarga Tenaga Kerja Wanita (Studi Fenomenologi TKW Pamekasan Yang Berimigrasi Ke Saudi Arabia Dan Malaysia). Penelitian tersebut menyimpulkan bahwa berimigrasi sangat berarti karena membawa banyak perubahan terhadap kehidupannya terutama yang berupa "aset rumah dan tanah", pendidikan anakanaknya dan pemenuhan hidup keluarga yang ditinggalkannya. Para TKW Pamekasan ini sudah dapat merubah tempat tinggalnya yang semula terbuat dari "gedek" menjadi rumah bangunan permanen.

5. Barang-barang koleksi (mobil, motor, lukisan, barang antik lainnya) 
Investasi dalam barang koleksi seperti motor dan mobil cukup diminati oleh TKW. Namun kebanyakan mereka hanya mampu membeli motor karena uang mereka lebih banyak digunakan untuk investasi dalam properti. Investasi dalam kendaraan mereka anggap penting karena untuk mendukung mobilitas. Didaerah pedesaan yang konturnya banyak tanah pertanian menimbulkan jarak yang cukup jauh untuk mencapai tempat yang strategis. Sehingga para TKW dan keluarganya memandang penting untuk berinvestasi dalam motor dan mobil.

Penelitian lain dilakukan oleh Raharto (2017) tentang Pengambilan Keputusan Tenaga Kerja Indonesia (TKI) Perempuan Untuk Bekerja Di Luar Negeri: Kasus Kabupaten Cilacap. Hasil penelitiannya menyimpulkan bahwa perempuan tidak memiliki pilihan selain bekerja di luar negeri, terutama karena pertimbangan faktor ekonomi.

6. Emas dan permata

Mayoritas responden berinvestasi dalam emas. Hanya tiga responden yang tidak berinvestasi dalam emas dan permata karena tidak menyukai perhiasan tersebut. Namun enam orang responden berinvestasi dalam emas. Investasi tersebut mereka pilih karena selain berinvestasi emas bisa dijadikan perhiasan. Investasi ini lebih tahan lama bila dibandingkan dengan tabungan. Selain jumlah yang mereka miliki rata-rata tidak terlalu banyak, juga karena mereka sayang menjual perhiasan yang mereka miliki.

Karlina dkk (2017) melakukan penelitian tentang Pengaruh Bekerja Di Luar Negeri Terhadap Tingkat Ekonomi Dan Perceraian. Hasil penelitian tersebut menyimpulkan bahwa sebelum bekerja ke luar negeri kehidupan ekonomi keluarga tergolong rendah tetapi sesudah bekerja di luar negeri menjadi kehidupan ekonomi mereka mengalami peningkatan yang signifikan. 
7. Mata uang asing

Tenaga kerja wanita yang menjadi responden dalam penelitian ini banyak yang menyimpan mata uang asing. Baik itu alasan karena masih bekerja di sana maupun mereka memiliki uang asing tersebut walau sudah kembali ke Indonesia untuk tabungan. Namun mayoritas TKW tidak lama memiliki uang asing tersebut karena mereka tidak memiliki penghasilan tetap setelah pulang dari luar negeri. Mata uang asing yang mereka miliki akan mereka tukar dengan rupiah jika mereka membutuhkan uang dan jika tabungan mereka telah habis.

Penelitian yang dilakukan oleh Raharto (2017) tentang Pengambilan Keputusan Tenaga Kerja Indonesia (TKI) Perempuan Untuk Bekerja Di Luar Negeri: Kasus Kabupaten Cilacap. Hasil penelitiannya menyimpulkan bahwa perempuan tidak memiliki pilihan selain bekerja di luar negeri, terutama karena pertimbangan faktor ekonomi. Inisiatif untuk bekerja umumnya datang dari perempuan sendiri, sedangkan anggota keluarga terutama ayah dan suami hanya memberikan persetujuan. Dengan demikian, perempuan sudah lebih memiliki kebebasan dan kepercayaan diri untuk memutuskan bekerja di luar negeri.

8. Obligasi

Hasil penelitian ini menunjukkan bahwa tidak ada responden yang berinvestasi dalam obligasi. Tidakadanya responden yang berinvestasi dalam obligasi karena ketidak tahuan TKW dan keluarganya mengenai obligasi. Pengetahuan tentang investasi dalam obligasi saja mereka tidak mengetahui, sehingga tidak mungkin mereka akan berinvestasi dalam obligasi. Kurangnya pengetahuan tentang obligasi sama halnya dengan kurangnya pengetahuan tentang saham. Hal ini karena pendidikan mereka yang tidak tinggi juga 
karena tidak adanya sosialisasi oleh lembaga yang terkait maupun pemerintah tentang investasi tersebut.

Obligasi berasal dari bahasa Belanda yaitu obligatie yang dalam bahasa Indonesia disebut dengan obligasi yang berarti kontrak. Dengan Keputusan Presiden RI Nomor 775/KMK 001/1982 disebutkan bahwa obligasi adalah jenis efek berupa surat pengakuan utang atas pinjaman uang dari masyarakat dalam bentuk tertentu, untuk jangka waktu sekurang-kurangnya tiga tahun dengan menjanjikan imbalan bunga yang jumlah serta saatpembayarannya telah ditentukkan terlebih dahulu oleh emiten (Badan Pelaksana Pasar Modal).

Secara umum, obligasi merupakan surat utang yang dikeluarkan oleh perusahaan kepada investor dengan janji membayar bunag secara periodik selama periode tertentu, serta membayar nilai nominalnya pada saat jatuh tempo. Para investor tersebut akan mendapatkan return dalam bentuk suku bunga tertentu, yang besarnya sangat bervariasi dan sangat bergatung pada penerbitannya. Pemegang obligasi mempunyai hak mendapatkan bunga yang tetap sesuai dengan kesepakatan, hak pengembalian nilai atau harga obligasi pada saat habis masanya dan hak untuk mengedarkan menjual pada orang lain.

\section{PENUTUP}

\section{A. Simpulan}

Informan yang berinvestasi dalam tabungan cukup banyak yaitu 6 orang sedangkan yang tidak berinvestasi dalam tabungan hanya 3 orang itu pun karena mereka masih bekerja diluar negeri dan uangnya dikirimkan ke Indonesia dan mempercayakan sepenuhnya kepada keluarga dalam pengelolaannya. Mayoritas TKW tidak berinvestasi dalam deposito, hanya satu orang yang pernah berinvestasi dalam deposito. 
Namun seiring berjalanya waktu setelah pulang ke Indonesia deposito itupun habis karena TKW tidak memiliki penghasilan, sehingga menggunakan uang depositonya untuk memenuhi kebutuhan hidup. Tidak ada TKW yang berinvestasi dalam bentuk saham. Hal ini karena ketidaktahuan TKW maupun keluarganya tentang investasi dalam bentuk saham.

Mayoritas responden berinvestasi dalam properti. Hanya dua orang responden yang tidak berinvestasi di properti karena alasan masih single dan juga karena uangnya akan digunakan untuk sekolah lagi. Responden yang memilih berinvestasi dalam properti karena di desa investasi propertilah yang lebih banyak dilakukan. Investasi dalam barang koleksi seperti motor dan mobil cukup diminati oleh TKW.

Mayoritas responden berinvestasi dalam emas. Hanya tiga responden yang tidak berinvestasi dalam emas dan permata karena tidak menyukai perhiasan tersebut. Namun enam orang responden berinvestasi dalam emas. Investasi tersebut mereka pilih karena selain berinvestasi emas bisa dijadikan perhiasan. Tenaga kerja wanita yang menjadi responden dalam penelitian ini banyak yang menyimpan mata uang asing. Baik itu alasan karena masih bekerja di sana maupun mereka memiliki uang asing tersebut walau sudah kembali ke Indonesia untuk tabungan. Tidak ada responden yang berinvestasi dalam obligasi. Tidakadanya responden yang berinvestasi dalam obligasi karena ketidak tahuan TKW dan keluarganya mengenai obligasi.

\section{B. Rekomendasi}

Berdasarkan hasil penelitian tersebut, ada beberapa rekomendasi yang dapat peneliti sampaikan:

1. Bagi Pemerintah, sebaiknya memberikan edukasi kepada masyarakat tentang jenis-jenis investasi yang bisa dimiliki masyarakat umumnya dan para TKW khususnya. Serta memberikan arahan serta pelatihan 
agar TKW dan keluarga TKW dapat menggunakan uang yang didapat untuk modal usaha, serta memberikan pendampingan kepada mereka dalam mengelola usaha mereka.

2. Bagi pihak yang terkait seperti Perbankan dan perusahaan sekuritas, sebaiknya memberikan edukasi kepada masyarakat khususnya didaerah pedesaan tentang jenis-jenis investasi seperti deposito, saham dan obligasi. Karena masyarakat desa selama ini belum mengetahui tentang jenis-jenis investasi tersebut.

3. Bagi penelitian yang akan datang, hendaknya meneliti tentang peluang usaha-usaha yang dapat dilakukan oleh para TKW sehingga mereka memiliki pendapatan setelah pulang ke Indonesia.

\section{Daftar Pustaka}

Abdul Aziz. 2010. Manajemen Investasi Syar'iah. Alfabeta. Bandung. Alsa, A. 2010. Pendekatan Kualitatif dan Kuantitatif Serta Kombinasinya dalam Penelitian Psikologi. Pustaka Pelajar. Yogyakarta.

Goble, Frank. 1987. A. Supratiknya, ed. Mazhab Ketiga, Psikologi Humanistik Abraham Maslow. Kanisius.

Hamidah dan Farida. 2017. Analisis Prioritas Investasi Keluarga Tenaga Kerja Indonesia (TKI) Di Kecamatan Babadan Kabupaten Ponorogo. Jurnal Akuntansi Dewantara Vol. 1 No. 1 April 2017.

Hanafi, Mahmud. 2017. Manajemen Keuangan. BPFE. Yogyakarta.

Hartono, Jogiyanto. 2016. Teori Portofolio dan Analisis Investasi. BPFE. Yogyakarta.

Indah Yuliana. 2010. Investasi Produk Keuangan Syariah. UIN MALIKI PRESS. Malang.

Karlina. 2017. Pengaruh Bekerja Di Luar Negeri Terhadap Tingkat Ekonomi Dan Perceraian. Social Science Education Journal, Vol. 4 No. 1.

Lalu Husni, 2014, Pengantar Hukum Ketenagakerjaan. Rajawali. Jakarta. 
Meolong, L. J. 2004. Metodelogi Penelitian Kualitatif. Bandung : PT. Remaja Rosdakarya.

Qur'an Surat Al Baqarah: 233

Qur'an Surat Ath Thalaq ayat 8

Qur'an Surat Ath Thalaq: 7

Raharto. 2017. Pengambilan Keputusan Tenaga Kerja Indonesia (TKI) Perempuan Untuk Bekerja Di Luar Negeri: Kasus Kabupaten Cilacap. Jurnal Kependudukan Indonesia. Vol. 12 No. 1 Juni 2017.

Senduk, S, 2004, Seri Perencana Keuangan Keluarga : Mencari Penghasilan Tambahan, Alex Media Komputoindo, Jakarta.

Sugiono. 2017. Interpretasi Dampak Keuangan Keluarga Tenaga Kerja Wanita (Studi Fenomenologi TKW Pamekasan Yang Berimigrasi Ke Saudi Arabia Dan Malaysia). Seminar Nasional Hasil Penelitian Universitas Kanjuruhan Malang 2017.

Sugiyono. 2010. Metode Penelitian Pendidikan (Pendekatan Kuantitatif, Kualitatif, dan R\&D). Bandung: CV. Alfabeta.

Sukirno, Sadono. (2004). Makro Ekonomi. Edisi Ketiga. Jakarta: PT. Raja Grafindo Persada.

Sumarsono,S., (2009), Teori dan Kebijakan Publik Ekonomi Sumber Daya Manusia, Cetakan I, Graha Ilmu, Yogyakarta.

Sunariyah, 2003. Pengantar Pengetahuan Pasar Modal, edisi ke tiga, UPPAMP YKPN, Yogyakarta.

Todaro, M.P., (2006), Pembangunan Ekonomi, Edisi 9, Penerbit, Pearson. Education Limitied. United Kingdom. 